\title{
The Populist Turn in Central and Eastern Europe: Is Deliberative Democracy Part of the Solution?
}

\author{
Silvia Suteu*
}

\begin{abstract}
The rise of populism in Central and Eastern Europe as a broader democratic crisis Developments in Hungary, Poland and Romania indicate failure of representative politics post-1989Reorienting politics towards a deliberative democratic culture can help answer the bottom-up critique exploited by populists - Citizen-centric deliberative approaches take seriously long-standing discontent with liberal democracy and can provide an alternative to populism
\end{abstract}

\section{Introduction}

The current rise of populism in Central and Eastern Europe has upended assessments about the consolidation of democracy, the impact of European Union (EU) integration, and the prospects of liberal constitutionalism in the region. Whereas they were seen as the primary examples of successful post-communist democratization, countries such as Hungary and Poland have more recently taken a turn towards illiberalism. Their governments' attacks on rule of law institutions, the press and civil society have often left analysts puzzled and have forced them to reconsider their initial optimistic evaluations of these transitions. In countries such as Romania, endemic corruption and weak institutions have long coexisted with populist discourse which may yet develop into populist state capture. Analysts have not only had to grapple with the question of how things went wrong, but also with what solutions might be found. ${ }^{1}$

Diagnosing the causes of the populist rise in these countries has been focused on two main factors. On the one hand, the failure of domestic institutions such as constitutional courts to become entrenched in the local constitutional landscapes or national legislatures to develop safeguards against populist capture or to adequately control the executive. The broader problem of weak institutions has been identified as a cause for their vulnerability. ${ }^{2}$ On the other hand, supranational institutions such as the European Union and the Council of Europe have been unable or unwilling to

\footnotetext{
* Dr Silvia Suteu is a Lecturer in Public Law at UCL's Faculty of Laws.

1 J. Rupnik, 'Hungary's Illiberal Turn: How Things Went Wrong', 23 Journal of Democracy (2012) p. 132; L.E. Herman, 'Re-evaluating the Post-communist Success Story: Party Elite Loyalty, Citizen Mobilization and the Erosion of Hungarian Democracy', 8 European Political Science Review (2016) p. 251; I. Krastev, 'The Unraveling of the Post-1989 Order', 27 Journal of Democracy (2016) p. 5. In fairness, some of these same scholars had been warning about the rise of populism in the region for at least a decade prior. See I. Krastev, 'The Populist Moment', Eurozine, 18 September 2007; J. Rupnik, 'From Democracy Fatigue to Populist Backlash', 18 Journal of Democracy (2007) p. 17; B. Bugaric, 'Populism, Liberal Democracy, and the Rule of Law in Central and Eastern Europe', 41 Communist and Post-Communist Studies (2008), p. 191. See also Blokker; Krygier; Kosar, Baros and Dufek (all in this issue).

2 B. Bugaric, 'A Crisis of Constitutional Democracy in Post-Communist Europe: "Lands in-between" Democracy and Authoritarianism', 13 International Journal of Constitutional Law (2015), p. 219.
} 
react forcefully enough to prevent and sanction the slide into populism. ${ }^{3}$ Stronger European sanctions for democratic backsliding in the region have thus been called for.

Unsurprisingly, the solutions proposed so far also follow these two axes. One recent study in this area, for example, looked for potential remedies either in the European framework of rule of law protections or in doctrines of substantive limits on constitutional amendment ${ }^{4}$-both efforts premised on the need to stymie populist forces and to return the populist genie in its bottle. Even scholars who acknowledge there to be a wider problem of democracy in this region - one involving an impoverished politics with underdeveloped civic participation and therefore insufficient public support for democratic institutions - primarily call for the strengthening of rule of law institutions as the remedy. ${ }^{5}$ In other words, the proposed solutions to the crisis of liberal democracy in Central and Eastern Europe tend to involve calls for more liberal democracy.

The first part of this article is an exploration of a deceivingly simple question: could we gain something valuable by analysing the rise of populism in Central and Eastern Europe not simply as a regional pathology, but as part of a broader crisis of democracy? ${ }^{6}$ Put differently, do we lose something crucial if only looking at the erosion of the rule of law and democratic guarantees in these countries through the prism of a failure of democratic consolidation distinctive to post-communist transitions? Is there fruitful ground for postulating a correlation between the recent populist phenomena in the region and a wider crisis of (liberal) democracy? And if there is, what might it mean that, in the words of JanWerner Mueller, 'democracy as a whole might have to change' in response?'

I argue that there is indeed such a correlation and that recognising it is necessary if our prescriptions for the way forward are adequately to fit the problem. Whereas I acknowledge the specificities of the regional context - such as the comparatively shorter practice of constitutional democracy as compared to their Western counterparts, as well as the fraught experiences of transition and European accession - I believe our analysis is mistaken if it divorces the rise of populism in Central and Eastern Europe and its critique of liberal democracy from broader discontent with liberal democracy. I therefore argue that the twin approaches discussed above - strengthening rule of law institutions and a more proactive role of the EU - are insufficient to address the current populist turn in this region. As solutions, they are incomplete. What is missing is an appreciation of the link between the populists' rise and a wider contestation of representative democracy, particularly in its (neo-)liberal form. In other words, enmeshed in and sometimes hidden by the populist discourse in these countries has been a very real popular discontent with traditional representative institutions and liberal democratic tenets as instantiated by the post- 1989 'new constitutionalism'. ${ }^{8}$

\footnotetext{
3 See, for example, J.W. Mueller, 'Eastern Europe Goes South: Disappearing Democracy in the EU's Newest Members', 93 Foreign Affairs (Mar/Apr 2014) p. 14.

${ }^{4}$ A. von Bogdandy and P. Sonnevend (eds.), Constitutional Crisis in the European Constitutional Area: Theory, Law and Politics in Hungary and Romania (Hart Publishing 2015).

${ }^{5}$ Bugaric supra n. 2.

${ }^{6}$ For an earlier editorial scrutinising the state of democracy within the EU, see 'Talking about European Democracy', 13 EuConst (2017) p. 207.

7 J.W. Mueller, What Is Populism? (University of Pennsylvania Press 2016) p. 72.

8 'New constitutionalism' has been understood as a shift, occurring in the twentieth century, towards increasing legalisation of the public sphere and juridification of political disputes. See, inter alia, M. Mandel, 'A Brief History of the New Constitutionalism, or "How We Changed Everything So That Everything Would Remain the Same"', 32 Israel Law Review (1998) p. 250 at p. 251 and R. Hirschl, Towards Juristocracy: The Origins and Consequences of the New Constitutionalism (Harvard University Press 2004). An exploration of the interplay between this shift and the neo-liberal economic policies that have gained dominance at the same time, particularly in Central and
} 
The second part of this article builds on this insight and looks to deliberative democracy for possible answers. Contrary to much writing in this area, the article asks whether constitutionalists should seek to encourage instead of limit popular input, but to channel this input through deliberative instruments and practices. There are several advantages to such a move. Citizens are said to be more likely to become involved and take ownership of its outputs; their decision-making capacity is said to increase because they are trusted as capable deliberative agents; and the focus on individuals may yet help circumvent groups or parties more prone to extremist agendas. Conversely, the potential drawbacks of a turn to deliberation centre on the many unknowns associated with the use and institutionalisation of deliberative mechanisms. While there is growing proof that exercises in micro-deliberation can empower citizens as decision-makers, yield measured and workable solutions, and sometimes overcome political deadlock, ${ }^{9}$ our lack of experience with these mechanisms across different contexts leaves them open to bad design, potential capture or simply shoddy implementation. They may also be insufficient to tackle macro-level discontent and a systemic deliberative approach may instead need to be developed. ${ }^{10}$ There is a further question as to whether, even assuming deliberation can deliver its promised gains, it could do so sufficiently quickly and robustly so as to trigger visible change in democratic practices before populists completely erode democratic institutions.

The article concludes that, rather than an alternative to the macro-level responses discussed above, the turn to deliberative democracy during this time of crisis in Central and Eastern Europe (and elsewhere) is a necessary but not sufficient solution. It has the advantage of directly addressing rather than ignoring the contestation of liberal democracy, while at the same time providing alternative avenues for decision-making and debate. Ultimately, deliberative democracy may wrestle popular discontent from populists using it to justify illiberal constitutional change and nationalistic policies and can facilitate more respectful national conversations and responsive institutions. Admittedly, this claim will be perceived as risky and controversial by many. However, I am not alone in looking at the current crisis as also a time of opportunity for reassessment. To existing calls to rethink our constitutional theoretical assumptions ${ }^{11}$ and understandings of democratic transition ${ }^{12}$ I add this invitation to broader-scale rethinking of our core democratic commitments.

\section{The Populist Turn in Central and Eastern Europe and the Crisis of Democracy}

\section{The Specificity of the Central and Eastern European Context}

My first proposition is that the populist illiberal turn in Central and Eastern Europe is not just a distinctly regional pathology in the way many have analysed it. ${ }^{13}$ This is not to say that it does not have

Eastern Europe, goes beyond the scope of this article. However, see L. Obendorfer, 'From New Constitutionalism to Authoritarian Constitutionalism: New Economic Governance and the State of European Democracy' in J. Jaeger and E. Springler (eds.), Asymmetric Crisis in Europe and Possible Futures Critical Political Economy and Post-Keynesian Perspectives (Routledge 2015) p. 186.

${ }^{9}$ K. Groenlund et al. (eds.), Deliberative Mini-Publics: Involving Citizens in the Democratic Process (ECPR Press 2014) and M. Reuchamps and J. Suiter (eds.), Constitutional Deliberative Democracy in Europe (ECPR Press 2016). $10 \mathrm{~J}$. Parkinson and J. Mansbridge (eds.), Deliberative Systems: Deliberative Democracy at the Large Scale, (Cambridge University Press 2012).

${ }^{11}$ L. Corrias, 'Populism in a Constitutional Key: Constituent Power, Popular Sovereignty and Constitutional Identity', 12 EuConst (2016) p. 6.

12 A.L. Dimitrova, 'The Uncertain Road to Sustainable Democracy: Elite Coalitions, Citizen Protests and the Prospects of Democracy in Central and Eastern Europe', 34 East European Politics (2018) p. 257.

${ }^{13}$ I acknowledge the problematic aspects associated with defining populism as a pathology to begin with, which implies a normative dichotomy between democracy and populism as its negation. As C.A. Parvu has argued, there is value - especially in the Central and Eastern European context - in defining populism as a symptom, or 
specific regional characteristics, but to avoid understanding the rise of populism in the region as an inevitability, an 'unintended consequence'. ${ }^{14}$ Several causes have been identified for the democratic backsliding of countries such as Hungary and Poland. The first among these refers to weak institutions, in particular rule of law institutions which were meant precisely to temper majoritarian excesses and quash attacks on liberal constitutionalism. ${ }^{15} \mathrm{~A}$ related cause refers to the poorly developed civil society of most countries in the region and weak civic participation, coupled with a widespread lack of trust in democratic institutions. ${ }^{16}$ By traditional measures, the raw numbers of civic participation in political life, such as voter turnout and party membership, have been consistently lower in Central and Eastern Europe than in their Western European counterparts. Whether this is true for all Central and Eastern European countries at all times and, even if so, whether it would be enough in itself to justify the rise in populism is somewhat more complicated, as will be seen shortly.

A second cause discussed in the literature has to do with these countries' socio-cultural contexts. An ethnic-based nationalism is said to have never really gone away and instead to have become legitimised following the collapse of communism. ${ }^{17}$ It is said to have shadowed these countries' transitions, taking the form of overt ethnic conflict in some instances, but also more nuanced constitutional nationalism in others. ${ }^{18}$ In Central and Eastern Europe, the tandem of populism and nationalism has been said to have 'the potential to produce powerful myths that can take whole societies hostage and become parasitic to modernization itself. ${ }^{\prime 19}$ The fact that ethnic nationalism has taken on populist garb and is being espoused by parties and politicians in power is then an exacerbation of an ailment that was always there. Examples abound, from Hungary's ethnic-based constitutional definition of the nation to Poland's particular brand of conservatism to the ethnic-based and xenophobic discourse having characterised Romania's 2014 presidential and 2016 parliamentary elections.

A third factor pinpoints the recent economic crisis as the trigger for shifts in attitudes in these societies that eventually welcomed populist actors. The worse the country's perceived economic performance, the more predisposed citizens are to vote in populists, the argument goes. ${ }^{20}$ This interpretation, known as the 'economic insecurity' thesis, therefore posits that 'rising economic insecurity and social deprivation among the left-behinds has fuelled popular resentment of the political classes', a resentment turned into electoral success by populist parties. ${ }^{21}$ However, contrary to early predictions

indicator, of a deeper democratic malaise. See C.A. Parvu, 'Syndrome or Symptom: Populist and Democratic Malaise in Post-Communist Romania' in M. Kopecek and P. Wcisik (eds.), Thinking Through Transition: Liberal Democracy, Authoritarian Pasts, and Intellectual History in East Central Europe after 1989 (CEU Press 2015) p. 259.

${ }^{14}$ I. Krastev, After Europe (Pennsylvania University Press 2017) p. 73.

${ }^{15}$ Bugaric supra n. 2.

${ }^{16}$ See discussion in J. Ekman et al., 'Challenges and Realities of Political Participation and Civic Engagement in Central and Eastern Europe', 32 East European Politics (2016) p. 1.

${ }^{17}$ A. Sajo, 'Preferred Generations: A Paradox of Restoration Constitutions', 14 Cardozo Law Review (1993) p. 847 at p. 854.

${ }^{18}$ S. Suteu, 'The Multinational State That Wasn't: The Constitutional Definition of Romania as a National State', 4 Vienna Journal of International Constitutional Law (2017) p. 413.

${ }^{19}$ Parvu supra n. 13 p. 264.

${ }^{20}$ See, for instance, N. Corbu and E. Negrea-Busuioc, “"Economy Matters!” People's Evaluation of Their National Economies and the Success of Populist Parties in Central and Eastern Europe', Paper presented at the ECPR 2016 General Conference, 7-10 September 2016.

${ }^{21}$ R.F. Inglehart and P. Norris, 'Trump, Brexit, and the rise of Populism: Economic Have-nots and Cultural Backlash', Paper presented at annual meeting of the American Political Science Association, Philadelphia, 2 September 2016, p. 2. This is different from arguments about populists' economic policies, which have been 
that the region would be the biggest loser of the economic crisis and that populists would capitalise on that crisis, ${ }^{22}$ the relationship between the economic crisis and populism in Central and Eastern Europe has been more complex. While worst affected countries such as Hungary did seem to confirm these predictions, other countries defied expectations for how their economies would fare during the crisis, as well as for how populists, whether in power or not, would behave. ${ }^{23}$ The latter certainly exploited the opportunities afforded to them by the turbulent economic waters, but it would be a mistake to attribute the populist rise solely to economic factors. As a recent study of several countries in the region has shown, populism there predated the economic crisis and built on deep public dissatisfaction with and distrust in democratic institutions. ${ }^{24}$ In other words, the economic crisis may have provided the opportunity for certain discourses and strategic positioning in countries hardest hit, but it is not the single cause of populism's appeal in Central and Eastern Europe. ${ }^{25}$

A final observation here refers to the role of the EU. On the one hand, it has been noted that no longer having levers with which to sanction democratic backsliding, or at least not direct ones as in the preaccession phase, has made the EU less able to react. Even the pre-accession Copenhagen criteria, designed to ensure new members proved their liberal constitutionalist credentials before joining the club, have been critiqued as overly general and too inconsistently applied to really have ensured norm diffusion. ${ }^{26}$ It is notable that the European Parliament has called for establishing a new mechanism to monitor compliance with Article 2 of the Treaty of the European Union (TEU) both before and after accession. ${ }^{27}$ In countries where monitoring continued after accession - the Cooperation and Verification Mechanism in Bulgaria and Romania, focused on the fight against corruption and organised crime - progress has been slow and gains appear vulnerable to reversal. ${ }^{28}$

On the other hand, the EU has never been explicit about its precise democratic commitments, preferring instead to promote democracy as linked to the protection of the rule of law. ${ }^{29}$ As part of

read as sharing reorientations to welfare chauvinism and economic protectionism as responses to the financial crisis. See S. Otjes et al., 'It's not Economic Interventionism, Stupid! Reassessing the Political Economy of Radical Right-wing Populist Parties', 24 Swiss Political Science Review (2018), p. 270.

${ }^{22}$ N. Roubini et al., 'Will The Economic Crisis Split East And West In Europe?', Forbes, 26 February 2009, available at $<$ https://www.forbes.com/2009/02/25/eastern-europe-eu-banks-euro-opinionscolumnists nouriel_roubini.html>, visited 20 August 2019.

${ }^{23}$ H. Kriesi and T.S. Pappas, European Populism in the Shadow of the Great Recession (ECPR Press 2015) at p. 318-319.

24 Ibid. at p. 3-4 and 315-316.

${ }^{25}$ B. Bugaric, for example, finds that Central and Eastern European populists' alternative economic policies are hugely appealing to their voters, but only in conjunction with ethnonationalism and authoritarianism. See his 'Central Europe's Descent into Autocracy: A Constitutional Analysis of Authoritarian Populism', 17 International Journal of Constitutional Law (2019) p. 597. See also Inglehart and Norris supra n. 21 at p. 4.

${ }^{26}$ Mueller supra n. 3.

27 See European Parliament Resolution of 3 July 2013 on the situation of fundamental rights: standards and practices in Hungary (pursuant to the European Parliament resolution of 16 February 2012) (2012/2130(INI)) at para. 74 and, more recently, European Parliament Resolution of 25 October 2016, A8-0283/2016, with recommendations to the Commission on the establishment of an EU mechanism on democracy, the rule of law, and fundamental rights.

${ }^{28}$ E. Zalan, 'Ten Years on, Romania and Bulgaria Still Dogged by Corruption', EUobserver, 25 January 2017.

${ }^{29}$ Mueller supra n. 7 at p. 58. For a more general discussion of the type of restrained democracy adopted in post-war Europe, see J.W., Contesting Democracy: Political Ideas in Twentieth-Century Europe (Yale University Press 2011) and P. Blokker, 'The Evolution of Constitutionalism in the Post-communist Countries of Central and Eastern Europe: Some Lessons for the Post-Soviet Space' in R. Petrov and P. Van Elsuwege (eds.), Post-Soviet Constitutions and Challenges of Regional Integration: Adapting to European and Eurasian Integration Projects (Routledge 2017) p. 5. 
the array of counter-majoritarian post-war institutions meant to prevent Europe's slide into authoritarianism, the EU embodies a set of supranational constraints on member states. ${ }^{30}$ For all the talk of a common European heritage and the codification of core values in Article 2 TEU, the EU as a normative actor has not primarily concerned itself with enforcing democratic standards. Even where it could rely on the technical analysis of expert bodies such as the Council of Europe's Venice Commission, the EU preferred a cautious approach to sanctioning democratic backsliding in the region. ${ }^{31}$ As such, for a long time its capacity to react to the populists in its midst remained limited to the vocabulary of the rule of law and did not include much in terms of answers to the attacks on democracy they advance. ${ }^{32}$ The attempt to link European political party funding to compliance with rule of law values has so far proven of limited impact. ${ }^{33}$ On the contrary, Eurosceptic and/or populist parties continued their attacks on European institutions and the European project during the 2019 European parliamentary elections, blasting them as elite-driven and far removed from national constituencies. $^{34}$

A further problem with appeals to the EU as the saviour in the current context is that European integration relied on, and thereby legitimated, some of the mechanisms since employed by populists to entrench their power. For example, delegated legislation was used extensively by accession states to implement the acquis, a move on which the EU was silent at the time. ${ }^{35}$ To this implicit endorsement of executive law-making we may add the broader endorsement of democracy 'from abroad' during Central and Eastern European countries' accession, ${ }^{36}$ together with the failure to rethink the European project in the aftermath of its Eastern enlargement. ${ }^{37}$ In at least some respects, then, the EU is faced with populists having turned the tables in terms of acceptable decision-making mechanisms while at the same time relying on a democratic critique of the Union itself not entirely without merit.

Given these diagnoses, it is hardly surprising that a first batch of proposed answers to the current crisis has been to seek to strengthen rule of law institutions, minority rights and civil society. Bojan Bugaric, for example, has proposed an array of solutions, including institutional strengthening and experimentation so as to have institutions that better fit these societies and which actually enforce

\footnotetext{
${ }^{30}$ Mueller supra n. 7 at p. 95.

${ }^{31}$ See J. Nergelius, 'The Role of the Venice Commission in Maintaining the Rule of Law in Hungary and in Romania' in von Bogdandy and Sonnevend supra n. 4 p. 291; A. Jakab and P. Sonnevend, 'Continuity with Deficiencies: The New Basic Law of Hungary', 9 EuConst (2013) p. 102.

${ }^{32}$ On mechanisms for rule of law protection in the EU, see C. Costa and D. Kochenov (eds.), Reinforcing Rule of Law Oversight in the European Union (Cambridge University Press 2016).

${ }^{33}$ Regulation (EU, Euratom) No 1141/2014 of the European Parliament and of the Council of 22 October 2014 on the statute and funding of European political parties and European political foundations, amended by Regulation (EU, Euratom) 2018/673 of the European Parliament and of the Council of 3 May 2018 amending Regulation (EU, Euratom) No 1141/2014 on the statute and funding of European political parties and European political foundations. For a critical assessment of these regulations, see J. Morijn, 'Responding to "Populist" Politics at EU Level: Regulation 1141/2014 and Beyond', 17 International Journal of Constitutional Law (2019) p. 617.

34 J. Dettmer, 'Populists Barnstorm Across Europe With Straightforward Message', VOA News, 20 May 2019, <https://www.voanews.com/europe/populists-barnstorm-across-europe-straightforward-message> accessed 20 August 2019.

35 D. Kochenov, EU Enlargement and the Failure of Conditionality: Pre-accession Conditionality in the Fields of Democracy and the Rule of Law (Wolters Kluwer 2007) at p. 140.

${ }^{36}$ Dimitrova supra n. 12 at p. 258.

37 J. Zielonka, Counter-revolution: Liberal Europe in Retreat (Oxford University Press 2018). This despite calls, at the time of enlargement, for it to trigger a reassessment of the European project as a whole. See J. Zielonka, Europe as Empire: The Nature of the Enlarged European Union (Oxford University Press 2006) and W. Sadurski, Constitutionalism and the Enlargement of Europe (Oxford University Press 2012).
} 
the rules (rather than the façade institutions many of these countries had created in their quest for a 'return to Europe').$^{38} \mathrm{Be}$ it courts (constitutional and ordinary) or the civil service, Bugaric sees the solution in their reform, such as by instituting meritocratic rules for appointment and further protecting their independence. To his credit, he also repeatedly mentions the need for deeper popular support for democratic institutions, albeit he does not say much about the concrete measures which could foster this improved civic engagement. Furthermore, such calls for fairer rules of the game echo findings in political science that, in Central and Eastern Europe, perceptions of procedural fairness are what drives trust in, and adherence to, the political system and democratic values. ${ }^{39}$

Another strand in scholarship has explored the availability of solutions within liberal constitutionalism itself. Doctrines of substantive limitations on constitutional amendments such as the unconstitutional constitutional amendment doctrine have been proposed as possible answers to instances in which constitutional change is used to undermine the rule of law and democracy. ${ }^{40}$ The content of the substantive norms against which to judge constitutional change as constitutional or not has differed - ranging from international and transnational law norms ${ }^{41}$ to moral standards such as the proposed amendment's consistency with human dignity and impact upon self-government. ${ }^{42}$ Common to such responses, however, is a belief that constitutional courts can and should be relied on to enforce these substantive limits. As developments in Hungary and Poland have shown, however, the success of measures aimed at undermining the judicial independence of these courts (such as court packing, changes to budgets, retirement ages and appointment rules, curtailment of judicial review powers) raises doubts as to whether they could indeed perform this task. This disabling of domestic rule of law institutions is precisely why some have put their faith in the intervention of external actors such the European Union, although that itself carries the limitations just discussed.

Thus, significant questions as to the appropriate array of solutions to the populists' rise in Central and Eastern Europe remain. One is: if the answer to the current populist crisis in the region is more liberal constitutionalism, what guarantees that it will stick this time around? Another is whether the search for tools of 'a more substantive conception of constitutionalism'43 is the only game in town. Might a more robust commitment to democracy, and to a different type of democracy than hitherto promoted, help?

\footnotetext{
${ }^{38}$ Bugaric supra n. 2 at p. 241-245.

${ }^{39} \mathrm{~J}$. Linde, 'Why Feed the Hand That Bites You? Perceptions of Procedural Fairness and System Support in PostCommunist Democracies', 51 European Journal of Political Research (2012) p. 410.

${ }^{40}$ See, inter alia, D. Landau, 'Abusive Constitutionalism', 47 UC Davis Law Review (2013) p. 189 and K. Kovacs, 'Changing Constitutional Identity via Amendment' in P. Blokker (ed.), Constitutional Acceleration within the European Union and Beyond (Routledge 2018) p. 199.

${ }^{41}$ L. Garlicki and Z.A. Garlicka, 'External Review of Constitutional Amendments: International Law as a Norm of Reference', 44 Israel Law Review (2011) p. 343; R. Dixon and D. Landau, 'Transnational Constitutionalism and a Limited Doctrine of Unconstitutional Constitutional Amendment', 13 International Journal of Constitutional Law (2015) p. 606.

42 Kovacs supra n. 40 at p. 210.

${ }^{43}$ Landau supra n. 40 at p. 260. Addressing Hungary specifically, Landau takes this further and raises the possibility of developing conceptions of unconstitutional constitutions to describe those that do not function in a certain way and adhere to certain principles. The latter idea is also developed in R. Albert, 'Four Unconstitutional Constitutions and Their Democratic Foundations', 50 Cornell Journal of International Law (2017) p. 169.
} 


\section{Central and Eastern European Developments in the Context of a Broader Crisis of Democracy}

I argue that not only are recent populist developments in Central and Eastern Europe an instance of this wider democratic crisis, but also that they have pursued two lines of attack. On the one hand, Central and Eastern Europe populists have challenged representative institutions, seeking to delegitimise them and replace them as the voice of 'the people'. On the other hand, they have pursued agendas of constitutional reform and replacement, aimed at entrenching populist control over institutions and eliminating pluralism. ${ }^{44}$ In other words, there is a double crisis at play: a crisis of representation and one of constitutionalism, at least in its liberal guise. In what follows, I briefly sketch the contours of both.

The crisis of representation in Central and Eastern Europe manifests itself in the erosion of the political sphere and lack of viable political opposition. Paul Taggart has observed populists' fundamental ambivalence towards representative politics, which they seek to supplant with variations of grassroots and direct democracy or even authoritarianism. ${ }^{45}$ There is scholarly consensus on the correlation between an impoverished political sphere and the rise of populism, in particular when the former amounts to an absence of a real opposition:

[T] he possibility of citizens identifying with political actors who visibly represent an opposition against current majority policies is crucial to the legitimacy of the political system as a whole. If citizens feel that they cannot oppose the political system from within, they easily tend to turn against the system itself. The system is experienced as an alienating form of political rule, over which citizens feel they have no control. In this context, the rise of populism has been analysed as a response of citizens to the overly consensual nature of contemporary politics. ${ }^{46}$

The latter consensus has been tied to the blurring of the lines between the political left and right and, in the EU, with the absence of any real opposition to push for policy alternatives and accountability. ${ }^{47}$ The general decline of party politics opens up opportunities for populists, who frame their platforms as protests against elitist party leaderships and advocate a type of partyless democracy premised on the unmediated relationship between the people and government. Thus, in 'populist democracy', the populist leader enjoys a direct relationship to 'the people', making the representation function previously played by parties superfluous. ${ }^{48}$

What sets the Central and Eastern Europe countries apart is that their entire post-communist paths have been largely underpinned by a similar elite-driven consensus: to embrace capitalism and free markets, as well as liberal democracy with very specific institutions, was from the onset presented as a necessity and no alternatives were considered. ${ }^{49}$ Little public justification or deliberation

\footnotetext{
${ }^{44}$ K.L. Scheppele, 'Autocratic Legalism', 85 University of Chicago Law Review (2018) p. 545.

45 P. Taggart, 'Populism and the Pathology of Representative Politics' in Y. Meny and Y. Surel (eds.), Democracies and the Populist Challenge (Palgrave 2002) p. 71. As will be discussed below, Central and Eastern European populists have not opted for the institutionalisation of direct democracy instruments, quite the opposite.

46 S. Rummens, 'Legitimacy without Visibility? On the Role of Mini-publics in the Democratic System' in Reuchamps and Suiter supra n. 9 at p. 135.

47 Ibid.

48 P. Mair, 'Populist Democracy versus Party Democracy' in Meny and Surel supra n. 46 p. 81 at p. 88-89. See, generally, P. Mair, Ruling the Void: The Hollowing of Western Democracy (Verso 2013). More recently, see N. Walker, 'Populism and Constitutional Tension', 17 International Journal of Constitutional Law (2019) p. 515.

${ }^{49}$ See, broadly, Krastev supra n. 14 at p. 61-106. See also Krygier, in this issue, discussing the challenges of not only institutionalising liberal democracy and the rule of law, but also of the failure to cope with the specifically political character of those challenges.
} 
accompanied these policy choices, neither in 1989 nor before or in the aftermath of EU accession. Furthermore, certain scholars have identified a link between the turn to populism and a crisis of the political class. Writing on post-accession Central and Eastern European politics, Alina Mungiu-Pippidi spoke of these countries' citizens growing increasingly fed up with 'the behavior of the improvised political class that has governed the region since 1990'; she predicted that, absent reform towards increasing accountability, 'voters are bound to turn to new alternatives [which] will frequently be populists of some stripe who capitalize precisely on this accountability deficit and who claim that they can offer a different brand of politics and politicians. ${ }^{150}$ The literature on populism has long recognised that populists often succeeded at inscribing unpopular or neglected items on the political agenda, ${ }^{51}$ which is confirmed in recent Central and Eastern European experience - see, for example, immigration in Hungary or marriage and reproductive rights in Poland.

Whatever the shortcomings of political parties as intermediaries between citizens and their representatives, their weakening leaves the door open for the claims of unmediated representation characteristic of populists. To quote Mueller again, 'populism is strong in places with weak party systems. ${ }^{152}$ When looking at raw numbers, the state of party politics in Central and Eastern Europe is far from rosy. Party organisation has been consistently lower than in Western Europe but also, and contrary to expectations that consolidation would ensue in time, party membership numbers have fallen in Central and Eastern Europe at an even higher rate than in older democracies. ${ }^{53}$ Many of those looking for answers to the populist rise in Central and Eastern Europe have therefore unsurprisingly advocated for the strengthening of political parties. Bugaric, for example, has identified 'establishing new, non-corrupt parties' as a promising strategy. ${ }^{54}$

One of the problems with such proposals is that the very conditions which these authors identify - a lack of trust in representative institutions, including political parties, chief among them - are the same that make the prospect of political parties, even new or reformed ones, currently succeeding in reshaping the political game difficult. One seemingly positive example is of a new political party set up in Romania before the 2016 parliamentary elections. The Save Romania Union (USR) brought together a mixture of younger individuals, many of them civic activists without prior political involvement, under an anti-corruption banner. It won nearly $9 \%$ of the vote and entered parliament. Its performance in the 2019 European parliamentary elections, in which it secured $22,4 \%$ of the vote in alliance with another new party, The Liberty, Unity and Solidarity Party (PLUS), would seem to confirm it as a redoubtable new political force. However, it was initially dogged by poor organisation, accusations of lack of funding transparency and an internal fight concerning its official position vis-àvis an initiative to modify the Romanian constitution so as to define the family as between a man and a woman. The latter in particular exposed the shortcomings of a political party not defining itself along any ideological lines. ${ }^{55}$ In other words, USR builds on rather than challenges the anti-party rhetoric

\footnotetext{
${ }^{50}$ A. Mungiu-Pippidi, 'EU Accession Is No "End of History"', 18 Journal of Democracy (2007) p. 12.

${ }^{51}$ C. Mudde and C. Rovira Kaltwasser, Populism: A Very Short Introduction (Oxford University Press 2017) p. 105.

52 Mueller supra n. 7 at p. 79.

${ }^{53}$ I. van Biezen, 'The Decline in Party Membership Across Europe Means That Political Parties Need to Reconsider How They Engage with the Electorate', EUROPP, 6 May 2013.

${ }^{54}$ Bugaric supra n. 2 at p. 242.

55 USR describes its membership as a pragmatic union between 'people on the left and on the right and the centre' and, given the urgency of the anti-corruption fight and the gap between politics and society, it claims not to 'have the right to be split...along ideological criteria' (my translations). Moreover, it describes corruption as affecting all other political parties and claims to wish to engage in a politics based on integrity and competence rather than ideology. See USR's FAQ page on their website, <https://www.usr.ro/intrebarifrecvente/\#ideologie> accessed 20 August 2019.
} 
prevalent in Romanian society and has in part owed its electoral success to this positioning. ${ }^{56} \mathrm{~A}$ similar 'post-ideological' and anti-corruption message characterises Momentum, the Hungarian political party also seeking to transcend left-right divisions and oppose Orban's FIDESZ. ${ }^{57}$ Both parties have taken self-described pragmatic approaches, primarily concerned with presenting workable alternatives to those in power and short term electoral gains. Their explicitly pro-European agendas are accompanied by an emphasis on technocratic government that signals they still view politics as a dirty word.

Another problem may stem from a misunderstanding of the nature of civic engagement in the region. Long identified with the failure of party democracy and traditional civil society to consolidate, civic engagement in Central and Eastern Europe has more recently come to be re-evaluated. ${ }^{58}$ Challenging easy assumptions about citizen involvement in politics, these newer analyses point to national citizenries which are largely interested in politics, despite their distrust of political institutions and poor evaluations of democratic performance. ${ }^{59}$ Stereotypically characterising Central and Eastern European citizens as 'civically passive' has more to do with ignoring atypical forms of civic engagement, some of which, such as the Ukrainian Maidan, have immense social impact. ${ }^{60}$ Another unexpected example is Romania's having experienced the largest post-communist mass protests in early 2017 despite consistently being placed at the bottom rung of civil society indexes. ${ }^{61}$ Hungary's 2018 mass demonstrations against the Orban government's so-called 'slave law' and Poland's protests against judicial reforms also signal the persistence of opposition to the ruling parties' agendas in both countries. ${ }^{62}$ In other words, the public sphere is less impoverished in these countries than previously thought; it is just that civic energies are directed elsewhere than in traditional organisations. Conditions of state capture also help explain this turn to informal channels of political mobilisation. ${ }^{63}$ As will be seen below, deliberative democracy has come to acknowledge the importance of this informal public sphere as a site of deliberation.

With regard to constitutions, the literature on populism also tells us that populist actors often embrace constitutional change as a means of stifling opposition and entrenching power. ${ }^{64}$ Central and Eastern European populists have confirmed that, far from being anti-institutionalists and ultimately

${ }^{56}$ A telling chant during the early 2017 anti-corruption protests in Romania was that 'all parties are the same filth'.

57 P. Hockenos, 'Hungary Finally Has an Opposition Worth a Damn', Foreign Policy, 17 January 2019, <https://foreignpolicy.com/2019/01/17/hungary-finally-has-an-opposition-worth-a-damn/> accessed 20 August 2019. Momentum gained nearly 10\% of the vote in the 2019 European parliamentary elections.

${ }^{58}$ See Ekman et al. supra n. 16; A. Marchenko, 'Civic Activities in Eastern Europe: Links with Democratic Political Culture', 32 East European Politics (2016) p. 12; R.S. Foa and G. Ekiert, 'The Weakness of Postcommunist Civil Society Reassessed', 56 European Journal of Political Research (2017) p. 419.

${ }^{59}$ Marchenko supra n. 58 at p. 22.

$60 \mathrm{lbid}$.

${ }^{61}$ A similar point is made about the 2013-2014 anti-government protests in Romania by D. Margarit, 'Civic Disenchantment and Political Distress: The Case of the Romanian Autumn', 32 East European Politics (2016), p. 46.

62 M. Dunai, 'Hungarian Protests Intensify as Orban Heads to Brussels', Reuters, 13 December 2018, <https://www.reuters.com/article/us-hungary-protest-idUSKBN1OC2OM> accessed 20 August 2019 and A. Koper and L. Kelly, 'Protests in Poland Condemn Controversial Judicial Reforms', Reuters, 16 July 2017, <https://www.reuters.com/article/us-poland-politics-protests-idUSKBN1A10S3> accessed 20 August 2019.

${ }^{63}$ Dimitrova supra n. 12 at p. 259. This is especially true in Hungary, where the Orban regime has been successful in changing electoral laws so as to further entrench its hold on power and disadvantage the political opposition.

${ }^{64}$ Mudde and Rovira Kaltwasser supra n. 51 at p. 84. 
unable to govern, populists can quite successfully embed their hold on power ${ }^{65}$ As the adoption of the 2011 Hungarian Basic Law has shown, 'populist constitutions' are an attractive tool in the populists' arsenal. Such constitutions may be justified as better reflections of the values of the political community, as identified by the populists themselves, but ultimately these constitutions do not necessarily privilege increased popular participation. ${ }^{66}$ Hungary's example is again telling, since the 2011 constitution actually reduced direct democracy: it reintroduced a high threshold for national referendums and eliminated popular initiatives and the National Assembly's ability to call national referendums. ${ }^{67}$ Viktor Orban has repeatedly justified the adoption and subsequent amendment of the 2011 Hungarian Basic Law as necessary for the 'modernisation' and 'renewal' of the country and as unequivocally authorised by the Hungarian people. ${ }^{68}$ Yet that has gone hand in hand with reducing the avenues available to political opponents and regular citizens from altering these reforms.

I would complement these observations with a comment about the place of constitutions and constitutionalism in Central and Eastern European societies. To the extent that they can be accurately described as such, ${ }^{69}$ these countries' constituent moments post-1989 were hardly participatory or deliberative. They were mostly drafted as elite pacts and have remained in many ways far removed from the societies which they govern. They have shut away rather than empowered the citizenry in these countries, all in the name of a distinctive type of liberal constitutionalism which has been promoted since 1989. This was a distinctly legal constitutionalism, focused as it was on countermajoritarian institutions such as constitutional courts, on rights protection and limiting government, but almost ignoring avenues for civic participation in government. ${ }^{70}$ It was based on distrust of citizens, not their empowerment, embodied in a rather thin electoral democracy. It is hardly surprising then that there is little attachment to constitutions in Central and Eastern European societies and a comparatively underdeveloped constitutional politics. ${ }^{71}$

One might contend that the picture above does not adequately capture reality across the region. In particular, one might point to Polish debates on the country's new constitution culminating in its 1997 adoption as evidence of precisely the type of participatory and deliberative process advocated for. However, Poland's protracted constitutional renewal was, according to Wiktor Osiatynski, delayed by rigid rules and the failure to clearly distinguish between constitution-making and ordinary politics. ${ }^{72}$ Osiatynski himself decried his initial optimism that the process would engender political consensus and civic education as naive; instead, political self-interest permeated constitutional negotiations and

\footnotetext{
65 Mueller supra n. 7 p. 62.

66 Ibid. at p. 63.

${ }^{67}$ For an assessment of direct democracy in post-1989 Hungary, see Z.T. Pallinger, 'The Uses of Direct Democracy in Hungary', Paper presented at the ECPR 2016 General Conference, 7-10 September 2016.

68 P. Karasz, 'Leader of Hungary Defends New Constitution', The New York Times, 7 February 2012, <http://www.nytimes.com/2012/02/08/world/europe/viktor-orban-defends-hungarys-new-constitution.html> accessed 20 August 2019.

${ }^{69}$ Ulrich Preuss, for instance, has referred to basic laws in Central and Eastern Europe as 'constitutions without a constituent power', which he has claimed has contributed to the fragile conditions of constitutionalism in the region. See U. Preuss, 'The Exercise of Constituent Power in Central and Eastern Europe' in M. Loughlin and N. Walker (eds.), The Paradox of Constitutionalism: Constituent Power and Constitutional Form (Oxford University Press 2012) at p. 228.

${ }^{70}$ P. Blokker, New Democracies in Crisis? A Comparative Constitutional Study of the Czech Republic, Hungary, Poland, Romania and Slovakia (Routledge 2014) at p. 5.

${ }^{71}$ A. Fruhstorfer and M. Hein, Constitutional Politics in Central and Eastern Europe: From Post-Socialist Transition to the Reform of Political Systems (Springer 2016). See also B. Puchalska, Limits to Democratic Constitutionalism in Central and Eastern Europe (Routledge 2016).

72 W. Osiatynski, 'A Brief History of the Constitution', 6 East European Constitutional Review (1997) p. 66.
} 
the momentum that had existed in 1989 was partially lost. ${ }^{73}$ The 1997 fundamental law was adopted by national referendum, but the $43 \%$ turnout can hardly have signalled widespread popular ownership. Similarly, the Romanian constitution's adoption in a national referendum with a 78\% 'Yes' vote risks obscuring the contested turnout (according to some reports, below 50\%) and the limited popular awareness of and interest in the draft, the latter of which had been adopted only two weeks prior to the referendum in an executive-dominated process marred by disinterest even amidst MPs. ${ }^{74}$ Thus, even those instances where civic participation in constitution-making has been praised are less impressive upon closer inspection.

Constitutions are only one illustration of how elite pacting underpinned the transitions in Central and Eastern Europe, all in pursuit of pre-defined ideals (market capitalism and liberal democracy) on which ordinary citizens were hardly if ever invited to deliberate. The fact that some of these constitutions were made extremely difficult to amend has also meant that modifying the initial pact has been a struggle and has also led to key changes being made informally. ${ }^{75}$ Not all of them were this rigid, however, as evidenced by Hungary's amendment rules requiring a two-thirds parliamentary majority and allowing for certain direct democracy mechanisms. However, not only have the avenues for citizen involvement been restricted during the Orban regime (see above), but citizen involvement in constitutional amendment had been prevented even under the pre-2011 constitution. The Hungarian constitution's openness has consistently favoured parliamentary majoritarianism rather than encouraging wide citizen engagement and deliberation - in Andrew Arato's words, 'the monopoly of a purely parliamentary revision rule' to the detriment of competing forms such as referendums. ${ }^{76}$ To this 'hollow core' at their constitutional births, Central and Eastern European countries saw added the emphasis on technocracy and top-down reforms during their transitions, none of which helped to engender a normative commitment to liberal democracy, let alone deeper civic engagement in politics. ${ }^{77}$

Saying that Central and Eastern European developments are connected to a wider crisis of democracy is not to dismiss their regional specificity, but to explain why certain attacks on representative institutions and liberal constitutionalism have been so successful. The populists' criticism of elites and, relatedly, of technocracy; their appeal for a rapprochement to the people; and their calls for the (re)politicisation of certain unpopular issues echo broader critiques of liberal democracy. Identifying these resonances is not to somehow justify populists' arguments as legitimate. As we have seen, in Central and Eastern Europe as elsewhere, their measures tend to be anti-pluralist and often antidemocratic. There is, however, a common kernel of discontent with liberal democracy which may help explain why populist ideas have found such a broad audience and why even staunch democrats may not always find it straightforward to dismiss all populist claims. Acknowledging that 'populism often asks the right questions but provides the wrong answers ${ }^{\prime 78}$ still requires us to think harder about 'the current failings of representation'79 as well as potential solutions.

\footnotetext{
73 Ibid. at p. 67.

74 See D.I. Pietraru, The Romanian Constitution of 1991: The "Stolen" Constitution, New School for Social Research, ProQuest Dissertations Publishing, 1997 at p. 151-274.

${ }^{75}$ An example of a particularly difficult to amend constitution in the region is Romania's, which also incorporates substantive limitations on constitutional change in Article 153. An example of informal constitutional change is Slovenia's, discussed by Bugaric supra n. 2 at p. 227-230.

${ }^{76}$ A. Arato, Civil Society, Constitution, and Legitimacy (Rowman \& Littlefield 2000) at p. 153.

77 Bugaric supra n. 25 at p. 609.

${ }^{78}$ Mudde and Rovira Kaltwasser supra n. 51 at p. 118.

${ }^{79}$ Mueller supra n. 7 at p. 103.
} 


\section{The Populist Turn in Central and Eastern Europe and Deliberative Democracy}

If we accept the proposition made in Part I, that we cannot dismiss developments in Central and Eastern Europe as divorced from a broader crisis of democracy, the question becomes whether the solutions proposed to address the illiberal turn in the region should also change. In other words, if the diagnosis changes, should the prescription as well? My answer is yes. As we saw above, policy-makers and scholars so far have focused on ways to defend liberal democracy in these countries. Less attention has been paid to the ways in which populist claims overlap with the critique of liberal democracy. ${ }^{80}$ Instead, the measures proposed are part of the liberal democrat's arsenal - stronger constitutional courts, stronger rights protection, oversight by supranational institutions - and are all premised on closing off the popular valve. In many ways, these accounts equate 'popular' and 'populist' and seek to extinguish both.

Even those who have noted the need for stronger popular participation in public life have either left it as an abstract desideratum ${ }^{81}$ or have argued for the benefits of direct recourse to the people (such as via referendums, popular initiatives etc.). ${ }^{82}$ While the latter would be a promising proposition in 'normal times', and while there are certain overlaps in the guiding principles of participatory and deliberative democracy, ${ }^{83}$ the risks associated with populist manipulation of direct democratic mechanisms such as referendums are obvious. As Stephen Tierney has argued, there is a case to be made for referendums being designed so as to be truly participatory and even deliberative exercises. ${ }^{84}$ However, the risk of 'elite control' is distinctly high in countries where populists are in power and can set the agenda and contours of any public vote on key issues. ${ }^{85}$

Instead, I propose to explore the promise of deliberative democracy in these turbulent times. In so doing, I agree with those who see in current times also an opportunity for rethinking our democratic commitments, and the institutions which embody them, at a deeper level. James Fishkin, for example, presents our options as follows:

We are in a period of dramatic mass disaffection from the political process in many countries around the globe. Such disaffection can be channelled into populism or it can be channelled into thoughtful redesign. Rethinking the prospects for deliberative democracy should be part of that dialogue. ${ }^{86}$

More recently, Fishkin has expressed the view that deliberation can help bridge the gap between distrusted elites and angry populists, neither of which should speak for the people and their values

\footnotetext{
${ }^{80}$ A notable exception is Paul Blokker. See, inter alia, his 'Populism as a Constitutional Project', 17 International Journal of Constitutional Law (2019) p. 536 and his discussion of populism as a critique of the 'logic of liberalism' in this issue.

${ }^{81}$ Bugaric supra n. 2.

${ }^{82}$ See essays in X. Contiades and A. Fotiadou (eds.), Participatory Constitutional Change: The People as Amenders of the Constitution (Routledge 2017).

${ }^{83}$ See S. Suteu and S. Tierney, 'Squaring the Circle? Bringing Deliberation and Participation Together in Processes of Constitution-Making' in Levy et al. (eds.), The Cambridge Handbook of Deliberative Constitutionalism (Cambridge University Press 2018) p. 282 and D. della Porta, Can Democracy Be Saved? (Polity Press 2013) at p. 35-84.

${ }^{84}$ S. Tierney, Constitutional Referendums: The Theory and Practice of Republican Deliberation (Oxford University Press 2012).

${ }^{85}$ Hungary's 2016 migrant quota referendum, albeit ultimately unsuccessful for the Orban government, is a good example of how the referendum tool can be used by populists in power.

${ }^{86} \mathrm{~J}$. Fishkin, 'Deliberative Democracy in Context: Reflections on Theory and Practice' in Groenlund et al. (eds.) supra n. 9 p. 27 at p. 38.
} 
without actually involving them in decision-making. ${ }^{87}$ Similarly, John Dryzek cautions against responses that aim simply to 'turn the clock back', which may work in isolated instances but will ultimately prove misguided and ineffective..$^{88}$ It may well be that strengthening institutions of the representative electoral system will improve the democratic process, but they will not answer calls for more opportunities for citizen input and control. ${ }^{89}$

Not all scholars of populism overlook this need for serious democratic reflection. Mueller, for instance, has contended that 'all is not well with Western [one could add Central and Eastern European] democracy' and that any defence of democracy must contend with the challenge posed by populists. ${ }^{90}$ He has also indicated he believes that populists should be engaged with rather than isolated - within the confines of the law - and that accurate information and argument can make a difference with electorates, even while they may not immediately shift emotive electoral behaviour. ${ }^{91}$ Mudde and Rovira Kaltwasser have also mapped the available responses to populists along a continuum between ostracising and engagement (provided the latter does not amount to adopting their message). ${ }^{92}$ Mueller's proposed solution, which he names but does not develop at the end of his 2016 study, is a renewed social contract, one which may be achieved via grand coalitions or other types of official renegotiations of constitutional settlements such as were implemented in Iceland and Ireland. ${ }^{93} \mathrm{He}$ does not say more about either the normative principles to guide such an endeavour or empirical illustrations. However, I believe deliberative democratic commitments are premised on precisely the type of inclusive renegotiation of fundamentals which he envisions, and the Icelandic and Irish examples are attractive precisely because they sought to translate hitherto abstract deliberative aims into constitutional practice.

\section{The Benefits and Limits of Deliberative Democracy in Populist Contexts}

The literature on deliberative democracy is too vast to cover here in any reasonable detail. ${ }^{94}$ For my purposes, it is sufficient to focus on the main tenets which inform this scholarship, as well as the promised benefits and potential pitfalls of deliberative democracy.

At its heart, deliberative democracy is premised on the idea that citizen's preferences are formed and transformed during discursive processes. Good communication, involving both speaking and listening, is key and argumentation is to be based on reasons acceptable to others. Because of the need to persuade others, participants in deliberative exercises are said to be able to move beyond self-interest and to embrace reasoned conceptions of the public good. Some deliberative democrats have emphasised consensus as the goal of deliberation, although this has been critiqued as ignoring the inevitability of conflict (especially in the political arena). Ultimately, deliberation is defined as 'a specific decision-making device likely to direct participants towards shared interests through high-

\footnotetext{
87 J. Fishkin, Democracy When the People Are Thinking: Revitalizing Our Politics Through Public Deliberation (Oxford University Press 2018) at p. 70.

88 J.S. Dryzek, Foundations and Frontiers of Deliberative Governance (Oxford University Press 2010) at p. 205.

${ }^{89}$ R. Dalton, Democratic Challenger, Democratic Choices: The Erosion of Political Support in Advanced Industrial Democracies (Oxford University Press 2004) at p. 204.

${ }^{90}$ Mueller supra n. 7 at p. 59-60.

${ }^{91} \mathrm{Ibid}$. at p. 84.

92 Mudde and Rovira Kaltwasser supra n. 51 at p. 116.

93 Ibid. at p. 98-99.

${ }^{94}$ For a good overview of key debates, see J.L. Marti and S. Besson (eds.), Deliberative Democracy and its Discontents (Routledge 2006). See also della Porta supra n. 83 at p. 60-84.
} 
quality debates. ${ }^{95}$ Deliberative democracy theory searches for the optimal way to enshrine it at the centre of our systems of governance.

One of the promised benefits of deliberative democracy is increased legitimacy of decision-making, especially at the input level. The search for the common good is a collective exercise in deliberation, and as such, deliberative democracy provides 'a normative account of the bases of democratic legitimacy'. ${ }^{96}$ Higher perceptions of legitimacy are also linked to increased trust in political institutions. ${ }^{97}$ At the output level, decisions will be more efficient and better implemented - the former because of the increased information citizens bring to the decision-making process, the latter because reasoned decisions in the public interest are more likely to attain citizen buy-in. ${ }^{98}$ Engagement in deliberative practice is also said to improve citizens' overall decision-making capacity. ${ }^{99}$ This educational aspect is especially important in the context of a rise in populism, as it may act as a counterweight to populist discourse. There is increasing evidence that civic education has an impact on the propensity of voters to support authoritarian/illiberal parties, including in Central and Eastern European countries. ${ }^{100}$

Deliberative democracy has not been without its critics, however, who have challenged both its underlying principles and their implementation. The theory has been challenged on many accounts: it has been accused of being elitist and ignoring deliberation from below; liberal deliberative theory in particular has been found to have an institutional bias, overlooking the numerous instances of informal deliberation; the link between the need to be conversant in a particular communicative style (or grammar) in order to have access to deliberation has been said to lead to inequalities; and the search for consensus has been attacked for excluding fundamental conflicts. ${ }^{101}$ In answer to these criticisms, a conception of democracy has been forged which is essentially both deliberative and participatory:

It calls for the formation of public spheres where, under conditions of equality, inclusiveness and transparency, a communicative process based on reason (the strength of the good argument) is able to transform individual preferences and reach decisions oriented to the public good. ${ }^{102}$

The deliberative democrats' emphasis on process - how decisions are made - is therefore complemented by an equal concern for participation - who is involved in making those decisions. The former challenges purely majoritarian processes, while the latter defies traditional notions of representation.

\footnotetext{
95 della Porta supra n. 83 at p. 177.

96 I.M. Young, 'Activist Challenges to Deliberative Democracy' in J. Fishkin and P. Laslett (eds.), Debating Deliberative Democracy (Blackwell 2003) p. 103. See also S. Benhabib, 'Towards a Deliberative Model of Democratic Legitimacy' in S. Benhabib (ed.), Democracy and Difference: Contesting the Boundaries of the Political (Princeton University Press 1996) p. 67.

97 J.S. Dryzek, Deliberative Democracy and Beyond: Liberals, Critics, Contestations (Oxford University Press 2000) p. 64.

98 della Porta supra n. 83 at p. 64.

99 della Porta 2013, p. 67.

${ }^{100}$ F. Fesnic, 'Can Civic Education Make a Difference for Democracy? Hungary and Poland Compared', 64 Political Parties (2016) p. 966.

${ }^{101}$ For a round-up of these objections, see della Porta supra n. 83 at p. 64-67.

102 lbid. at p. 67.
} 
A deliberative turn may also have an important symbolic significance in populist-embattled democracies, especially Central and Eastern European ones. It can perform an important signalling function, indicating that decision-making would be done differently and that citizens are themselves to play important roles at key moments: '[d]eliberative moments are themselves performances and symbols, communicating something important about the status of citizens, about the proper procedure, about "the way we do things". ${ }^{103}$ As already mentioned, post-1989 constitution-making in Central and Eastern Europe was from the onset confined to the limits of liberal constitutional (and free market) choices, with citizens at best playing a marginal role - such as in ratificatory constitutional referendums. There were already then voices cautioning that such a 'demobilization' of the population would result in legitimacy problems, given that the people would 'not come to think of the democratic republic as its own creation' and would consequently become alienated from democratic politics. ${ }^{104}$

There is a direct link to populism here. Writing on liberal democracy more generally, Mueller has argued that any system based on such deep distrust of its citizens is vulnerable to political actors who claim to give voice to the otherwise disempowered people. ${ }^{105}$ The claim is central to populists, even while they may not proceed to adopt more participatory or direct democratic elements once in power. ${ }^{106}$ Such appeals have special resonance in Central and Eastern Europe, where it would indeed be difficult to argue that democratic transitions were not elite-driven and non-participatory. Indeed, Mudde and Rovira Kaltwasser see a correlation between the popularity of populist discourse and transition by elite pact as in both Hungary and Poland, with populist actors justifying their attempts at constitutional change as amounting to the real revolution the countries did not have in $1989 .{ }^{107}$ Therefore, embracing deliberation may provide a way to address such demands while at the same time resisting populists' illiberal and anti-pluralistic answers. If 'talking to populists is not the same as talking like populists', ${ }^{108}$ the way to avoid doing so may indeed be to choose a deliberative path forward.

There is another way in which deliberation may yield symbolic gains and simultaneously defuse populist appeal. Given its emphasis on equality and inclusion, deliberative democracy should result in more inclusive decision-making, meaning both that a greater diversity of individuals and groups are involved in the decision-making (and therefore a greater variety of interests are taken into account) ${ }^{109}$ and that divisive and potentially violent identity-based claims are defused. ${ }^{110}$ This provides an alternative for another oft-encountered populist claim: that they represent the hitherto silenced voices, such as the indigenous peoples of Bolivia or Turkey's Anatolian 'Black Turks'. ${ }^{111}$ Mueller has spoken of the importance of engaging with populists on a symbolic level, whether it be 'arguing about what a polity's foundational commitments really mean' or 'the symbolic affirmation of parts of the

\footnotetext{
103 J. Parkinson, 'Ideas of Constitutions and Deliberative Democracy: A Conceptual Conclusion' in Reuchamps and Suiter (eds.) supra n. 9 at p. 154.

${ }^{104}$ A. Arato, 'Constitutions and Continuity in the East European Transitions Part I: Continuity and Its Crisis', 1 Constellations (1994) p. 92 at p. 103.

105 Mueller supra n. 7 at p. 96.

106 Ibid.

107 Mudde and Rovira Kaltwasser supra n. 51 at p. 37.

108 Mueller supra n. 7 at p. 84.

109 S. Wheatley, 'Deliberative Democracy and Minorities', 14 European Journal of International Law (2003) p. 507.

110 J.S. Dryzek, 'Deliberative Democracy in Divided Societies', 33 Political Theory (2005) p. 218.

${ }^{111}$ Mueller supra n. 7 at p. 85.
} 
population that had previously been excluded. ${ }^{112}$ While he does not provide illustrations of how this affirmation may be pursued, recent experience with deliberative instruments may provide clues.

Before proceeding, I should clarify what type of claim I am making here. As John Parkinson has usefully clarified, claims about deliberative democracy can range from arguments about adopting specific techniques of public engagement to those (such as his own) advocating for a system having deliberation as a salient feature. ${ }^{113}$ In other words, we can mean different things when we describe a democracy as deliberative: that it incorporates a number of deliberative mechanisms (such as minipublics) at various levels; that it requires deliberative practices of its institutions and actors (such as that they employ public reason in both making and justifying their decisions); or else that the overall system is deliberative, even if particular institutions or interactions are not. ${ }^{114}$

Similarly, deliberative constitutional democracy can have different meanings. Parkinson distinguishes between a model in which deliberation is pursued only within the confines of existing constitutional rules (leaving open only the question of the best way for groups to mobilise in order to influence the constitutional agenda) and a second-order or meta-model which opens up to deliberation the very rules of the game. The former is more pragmatic, in that it understands deliberation to be about the current contents of the constitution, whereas the latter refers to a more far-reaching type of deliberation about rights and procedures. ${ }^{115}$ Scholarship in this area - termed by some 'the law of deliberative democracy' - has grown significantly in recent years and has addressed questions of institutional design and constitutional theory long posed by constitutionalists. ${ }^{116}$ It has also addressed the conundrum of advocating for deliberative constitutionalism during populist times, especially given the propensity to confuse the two. As Simone Chambers has forcefully argued, however, the two can and must be distinguished, with the former offering a way forward that shows '(a) the ways in which citizens can participate in constitution-making without hijacking constitutionalism for majoritarian, nationalist and authoritarian ends; and (b) the important freedoms (especially the freedoms to oppose, disagree and criticise power holders) that constitutions must protect to be minimally considered democratic constitutions. ${ }^{117}$

In the remainder of this article, I will resort to a mixture of macro- and micro-level understandings of deliberative constitutional democracy. While I will be giving some examples of concrete ways to make institutions more deliberative, or concrete deliberative instruments which can themselves be institutionalised, my main aim in this article is not to offer a full array of institutional options. Instead, it is to argue for a reorientation of the very search for solutions to the turn to populism and illiberalism in Central and Eastern Europe towards deliberative democracy. Both the principles and, increasingly, the practical instantiations of deliberative democracy may offer the missing link in terms of solutions to the populist ills of the region. It is really a call to do politics, and constitutionalism, differently. ${ }^{118}$

\footnotetext{
112 Ibid.

113 Parkinson supra n. 103 at p. 147-162.

${ }^{114}$ The latter is the approach proposed by adherents of the systemic turn in deliberative democratic theory. See Mansbridge and Parkinson supra n. 10.

115 Parkinson supra n. 103 at p. 155.

${ }^{116}$ R. Levy and G. Orr, The Law of Deliberative Democracy (Routledge 2017) and Levy et al. (eds.) supra n. 83.

117 S. Chambers, 'Afterword: Populist Constitutionalism v. Deliberative Constitutionalism' in Levy et al. (eds.) supra n. 83 p. 370 at p. 371.

${ }^{118}$ As such, my argument shares important similarities with democratic constitutionalists such as Joel Colon-Rios and Paul Blokker, who argue that a substantial degree of openness and responsiveness of the constitutional system is vital to democracies. See J. Colon-Rios, Weak Constitutionalism: Democratic Legitimacy and the
} 


\section{Deliberative Experimentation and Its Prospects in Central and Eastern Europe}

In what follows, I propose to examine some of the recent experimentation with deliberative instruments. ${ }^{119}$ The list includes: deliberative mechanisms instituted at the central and the local levels; innovations meant to tackle wholesale constitutional renewal, piecemeal constitutional reform or else deliberative approaches to decision-making in particular policy areas (environment, health); deliberative practices adopted within existing institutions or else experimentation with mini-publics designed from the onset on the basis of deliberative principles. These examples show that deliberative democracy has begun to move from a set of theoretical propositions to practical instantiations complementing representative institutions.

One potential application of deliberative democratic principles would thus be the adoption of deliberative innovations in various areas of public decision-making. Mini-publics have recently garnered much attention in scholarship and practice, not least due to the highly visible 'crowdsourced' Icelandic constitution and Ireland's experience with now two constitutional conventions. ${ }^{120}$ While the outcome of both of these has been cause for some disappointment - the 'crowdsourced' Icelandic draft was ultimately not adopted and only a small percentage of the first Irish convention's recommendations were acted upon by the government - there are different ways to evaluate their success. The law may not have changed in either instance, but there is an argument to be made that such mechanisms have succeeded in changing the agenda, or imposing a new norm about how decisions are to be made. ${ }^{121}$ Another possible sign of success may be the diffusion of these mechanisms as models for constitutional reform, an example being interest in them as a tool for constitutional reform in Scotland (before the 2014 independence referendum and again in the aftermath of a possible second referendum) and in the UK as a whole (as a way to enact wide-ranging constitutional change before the EU referendum and as a way to overcome Brexit deliberation impass in the referendum's aftermath). ${ }^{122}$

It is not just in constitution-making that deliberative instruments have become attractive. The same potential for inclusive decision-making with high levels of legitimacy that makes them particularly attractive in the realm of negotiating constitutional choices has also made these mechanisms suitable to decision-making in fraught policy areas. Citizen assemblies in British Columbia, The Netherlands and Ontario were the first to experiment with deliberative change of electoral systems. The obvious advantage of asking regular citizens to learn and deliberate upon electoral rules was that they would not be self-interested in the way politicians making these decisions would be. There again, change in the law ultimately did not happen for various reasons, but it is undeniable that these mechanism have

Question of Constituent Power (Routledge 2012) and P. Blokker, 'Constitutional Reform in Europe and Recourse to the People' in Contiades and Fotiadou supra n. 82 p. 31 at p. 40-42.

119 For studies of deliberative democracy in practice, see, inter alia, R.E. Goodin, Innovating Democracy: Democratic Theory and Practice After the Deliberative Turn (Oxford University Press 2008); D. Kahane et al. (eds.), Deliberative Democracy in Practice (UBC Press 2010); M.A. Nebo, Deliberative Democracy between Theory and Practice (Cambridge University Press 2015).

120 Groenlund et al. (eds.) supra n. 9.

121 Parkinson supra n. 103 at p. 160.

122 S. Suteu, 'The Scottish Independence Referendum and the Participatory Turn in UK Constitution-making: The Move Towards a Constitutional Convention', 6 Global Constitutionalism (2017) p. 184; J. Gallagher, 'Citizens' Assemblies: Breaking the Brexit Deadlock?', The Constitution Unit Blog, 5 April 2019, <https://constitutionunit.com/2019/04/05/citizens-assemblies-breaking-the-brexit-deadlock/> accessed 20 August 2019; and Scottish Government, 'Citizens' Assembly of Scotland', 26 June 2019, <https://www.gov.scot/news/citizensassembly-of-scotland-1/> accessed 20 August 2019. 
had a considerable demonstration effect elsewhere. ${ }^{123}$ Such innovations have also been tested in the field of healthcare, where priority-setting in the context of limited resources and unlimited demand is particularly open to disagreement, ${ }^{124}$ as well as in the environmental policy area, where deliberation has been said to aid in tackling complex and often contradictory values. ${ }^{125}$ Experimentation with participatory and deliberative instruments has been especially well-suited to the local level, where citizens can more easily perceive decision-making as having an impact on their daily lives. A good example of such an instrument has been participatory budgeting, wherein ordinary citizens are involved in deciding how to allocate part of a local budget. ${ }^{126}$

The above examples have focused on institutional innovations, in particular those that empowered citizens as decision-makers, whether alongside or instead of politicians. Deliberative democratic advances have also been made in terms of making representative institutions more deliberative. One example would be political parties. Recent studies have rejected the hypothesis of a decline in popular interest and engagement in politics, arguing instead that it is political parties' failure to reform their internal structures along deliberative lines which continues to deter partisan mobilisation. ${ }^{127}$ Other examples include making parliaments and even executives more deliberative. The former in particular are natural candidates for becoming deliberative spheres, although any in-depth study of the actual workings of a national assembly tends to reveal that it is seriously deficient in this area. Deliberative democrats have proposed concrete steps which can be taken to reform the operation of parliaments so as to move them away from aggregative decision-making by temporary majorities and closer to the type of inclusive pursuit of the public good they were arguably always meant to embody. ${ }^{128}$

For the longest time, critics of deliberative democracy accused its proponents of engaging in ideal theory-in other words, they saw deliberative goals as unattainable in practice. ${ }^{129}$ What the above, albeit brief, exploration of recent practical advances shows is that we have come a long way from the time when such arguments could be made. Still unknown, however, are the prospects of success of such innovations. On the one hand, in terms of actually empowering citizens as decision-makers, the evidence so far has been mixed. ${ }^{130}$ This may at least partially be due to the very novelty of these mechanisms, many of which still require further calibration and better integration with other institutions before they can deliver. It is likely also the case that very high expectations are placed on what are often isolated innovations - a citizens' assembly or citizen jury being expected to fix all of

\footnotetext{
123 P. Fournier et al. (eds.), When Citizens Decide: Lessons from Citizen Assemblies on Electoral Reform (Oxford University Press 2011) p. 28.

${ }^{124}$ H. Raisio, 'The Public as Policy Expert: Deliberative Democracy in the Context of Finnish Health Care Reforms and Policies', 6 Journal of Public Deliberation (2010) p. 1.

125 G. Smith, Deliberative Democracy and the Environment (Routledge 2003).

${ }^{126}$ See J. Talpin, Schools of Democracy: How Ordinary Citizens (Sometimes) Become Competent in Participatory Budgeting Institutions (ECPR Press 2011).

${ }^{127}$ C. Invernizzi Accetti and F. Wolkenstein, 'The Crisis of Party Democracy, Cognitive Mobilization, and the Case for Making Parties More Deliberative', 111 American Political Science Review (2017) p. 97.

${ }^{128}$ See, for example, J. Uhr's Deliberative Democracy in Australia: The Changing Place of Parliament (Cambridge University Press 1998). For a discussion of the United States executive as deliberative, see C.R. Sunstein, 'Deliberative Democracy in the Trenches', 146 Daedalus (2017) p. 129.

$129 \mathrm{~J}$. Bohman could still decry, in 1998, 'a surprising lack of empirical case studies of democratic deliberation at the appropriate level and scale.' See J. Bohman, 'The Coming of Age of Deliberative Democracy', 6 Journal of Political Philosophy (1998) p. 400 at p. 419.

${ }^{130}$ della Porta supra n. 84 at p. 179-180 and Talpin supra n. 126.
} 
representative democracy's woes. ${ }^{131}$ Better connecting such deliberative mini-publics to both decision-makers (and the formal institutional structure) and the wider public (the informal public sphere) is crucial. ${ }^{132}$ It is also here that deliberative systems theorists' insights on doing deliberation on a large scale become more relevant. ${ }^{133}$

At the same time, though, the definition of success in this context may need to be adjusted as well. As mentioned already, in some instances, the fact that citizens could come together and deliberate on thorny issues could itself be seen as the breakthrough, even while their impact on policy-making or constitutional change may not have been immediate. Or, as Donatella della Porta has argued, deliberative exercises may be seen as effective bridging arenas between institutions and citizens. ${ }^{134}$ Under the current conditions of a retreat from party politics, filling this gap may indeed be an important achievement.

When it comes to Central and Eastern Europe, participatory and even deliberative democracy is not entirely alien to it. Examples include innovations at both the local level, such as the use of participatory budgeting, and the national level, such as the recourse to participatory forums in processes of constitutional reform. An example of the former is experimentation with participatory budgeting in various cities, such as in Romania or Poland. ${ }^{135}$ Even before these, there was experience with community funds, allotted and administered locally in a reasonably deliberative manner. ${ }^{136}$

An example of experimentation in the area of constitutional change are Romania's 2003 and especially its 2013 Constitutional Forums - bodies made up of civil society actors and individual citizens tasked with debating and making recommendations on constitutional reforms. ${ }^{137}$ While these mechanisms may be seen more as participatory experiments, given their focus on reaching as wide an audience as possible rather than emphasising also the method of engagement, they did incorporate deliberative aspects. The 2013 Forum in particular was designed so as to maximise participation as well as ensure that a plurality of viewpoints were heard and debated. At the same time, it is true that these mechanisms remained subject to the whims of their political makers, who ultimately decided on the fate of constitutional renewal in a non-transparent manner without accounting for any of the Forum's inputs. Thus, despite apparent attempts at participatory and even deliberative legitimation, Romania's constitutional politics has not really moved beyond being a form of 'populist-majoritarian constitution-making'. ${ }^{138}$

\footnotetext{
${ }^{131}$ On the limits of piecemeal use of citizens' juries in the United Kingdom, see P. McLaverty, 'Is Deliberative Democracy the Answer to Representative Democracy's Problems? A Consideration of the UK Government's Programme of Citizens' Juries', 45 Representation (2009), p. 379.

132 Parkinson supra n. 103 at p. 162.

133 Parkinson and Mansbridge supra n. 10.

134 della Porta supra n. 84 at p. 183.

135 See, for instance, the ongoing participatory budgeting initiatives in Cluj-Napoca, Romania: <https://bugetareparticipativa.ro/> accessed 20 August 2019 and emulated in further Romanian cities. See also D. Kamrowska-Zaluska, 'Participatory Budgeting in Poland - Missing Link in Urban Regeneration Process', 161 Procedia Engineering (2016) p. 1996.

${ }^{136}$ For a discussion of such a fund in the Polish city of Plock, see Y. Sintomer et al., 'Participatory Budgeting in Europe: Potentials and Challenges', 32 International Journal of Urban and Regional Research (2008) p. 164.

${ }^{137}$ For a good overview of the two bodies and their place among Romania's constitutional moments, see $P$. Blokker, 'The Romanian Constitution and Civic Engagement', 11 Vienna Journal of International Constitutional Law (2017) p. 437.

${ }^{138}$ Blokker supra n. 118 at p. 51.
} 
For the most part, however, it is fair to say that Central and Eastern Europe has not been at the forefront of deliberative experimentation. Leaving aside questions of resource availability, it is worthwhile asking two questions. The first is whether countries in the region can fulfil the preconditions that would make a turn to deliberative democracy possible, whatever those are. The second is whether deliberation has any promise in populist times or whether it is more of a fair weather luxury. Put more bluntly: could deliberative democracy work in Central and Eastern Europe under the best of times, and even if so, what chances for it under the worst of (populist) times?

Identifying deliberative democracy's preconditions is not always easy, and its theorists often embrace unstated assumptions which are later disproven by practice. Among these stated and unstated presuppositions are: rationality and openness to be persuaded, in the Habermasian tradition; the reasonable justness of society and its peoples being well-ordered, in the Rawlsian tradition; and conditions associated with citizen capacity to engage, such as literacy, numeracy or a minimum threshold of socio-political equality. ${ }^{139}$

Nevertheless, empirical studies have contested the emerging notion that deliberative democracy is 'limited to conditions of advanced modernity'. ${ }^{140}$ They have argued that while these conditions may facilitate deliberation, they are not necessary for it. Provided there is interest in the topic of deliberation, citizens in less affluent societies can still engage in a meaningful way. As was seen above, the main driver of civic engagement in Central and Eastern Europe is political interest, so at least a priori engagement in deliberation could be appealing to citizens provided it touches on items they deem important. Similarly, empirical work has demonstrated that, under the right conditions, a great degree of learning happens during deliberative exercises, empowering citizens to make fully informed decisions. ${ }^{141}$ This may thus help alleviate doubts that Central and Eastern European citizens would be able to 'understand this more subtle form of democracy' taking place outside traditional institutions. ${ }^{142}$ It is not to deny the difficulties - as some have put it, '[d]eliberative democracy is by definition more demanding than aggregative democracy alone ${ }^{\prime 143}$ - but to argue that they are not insurmountable.

A second, more pressing question, is whether deliberative democracy should even be on the agenda in times of populism. Prescriptions for deliberative practices and instruments involve a degree of experimentalism and openness, which unavoidably imply an element of risk. It may seem particularly ill-advised to be suggesting that opening up the public sphere and promoting deliberative engagement is the way forward in contexts where populism has made significant inroads. Talk of a 'post-truth' era is also relevant to Central and Eastern Europe, where media capture and attacks on academic freedom are especially worrying. ${ }^{144}$

And yet, we know that citizens are not disengaged politically but rather feel angry and disempowered with the current way of doing politics - a finding which was noted above vis-à-vis Central and Eastern

\footnotetext{
${ }^{139}$ M. Gupte and R.V. Bartlett, 'Necessary Preconditions for Deliberative Environmental Democracy? Challenging the Modernity Bias of Current Theory', 7 Global Environmental Politics (2007) p. 94.

140 Ibid.

${ }^{141}$ Fournier et al. supra n. 123.

${ }^{142}$ Andras Sajo makes this point, albeit referring to a deliberative turn in the EU. See A. Sajo, 'Constitution without the Constituent Moment: A View from the New Member States', 3 International Journal of Constitutional Law (2005) p. 243 at p. 260.

143 Gupte and Bartlett supra n. 139 at p. 95.

${ }^{144}$ On deliberative democracy during the 'post-truth' era, see N. Curato et al., Power in Deliberative Democracy Norms, Forums, Systems (Palgrave Macmillan 2019) at p. 137-172.
} 
Europe and which is also true of Western democracies. ${ }^{145}$ To the extent that populism is the only game in town when it comes to giving a voice to their grievances, its appeal is obvious. However, deliberative democracy offers a powerful rhetorical counter-attack. Insofar as deliberative institutions seek to bring in marginalised voices and empower individuals as active citizens, they can offer a counterweight to populists' claims of embodying the unmediated voice of the people. To quote Chambers again, '[d]eliberative constitutionalism, because it invests popular sovereignty in processes of collective egalitarian discourse rather than in outcomes of majoritarian procedures or an identifiable general will, is in a good position to offer a critical yardstick for questioning the democratic credentials (not just liberal) of populist constitutionalism. ${ }^{146}$ In other words, deliberative constitutionalism can expose the hypocrisy of populists claiming to be committed democrats. It can also harness and build on the potential of new forms of media to combat the capture of traditional media by state forces. Last but not least, deliberative mechanisms fosters 'civility and argumentative complexity' - key components of a healthy democracy which populism has consistently eroded. ${ }^{147}$

However, it is not just as a rhetorical counterweight that deliberative democracy can operate in a populist context. Deliberative mechanisms may offer concrete models of overcoming polarisation and even political deadlock. Take for instance the citizens' assembly on Brexit that was run as an academic experiment in September 2017. Fifty randomly selected participants, chosen so as to be both statistically representative of the wider population and proportionately representative of the referendum vote, were brought together to deliberate on the country's future relationship to the EU. They were provided with balanced information on the issues, the ability to question experts, and adequate time to form an opinion and discuss it with the other participants. The results of these deliberations surprised even the organisers: participants were able to form nuanced positions on complex issues such as trade and migration, going beyond the polarised debates in the political arena. Their views also shifted as they engaged in the process. While the experiment was small scale, it did demonstrate the potential gains of injecting more deliberation into an otherwise embittered context subject to its own populist arguments. ${ }^{148}$ It showed that, when looking for viable tools to overcome the current polarisation of politics and of the wider public sphere in Central and Eastern Europe and elsewhere, deliberative democracy might provide some answers.

Of course, one might still ask how we move towards such a deliberative model in the first place, in particular under conditions of populist state capture. Proponents of such a deliberative turn have themselves acknowledged that 'deliberative democratization will not just happen' but will depend on political will and popular pressure. ${ }^{149} \mathrm{~A}$ scenario such as Ireland's, where citizens' assemblies appear headed towards institutionalisation in a constitutional system already open to participation in the form of referendums, may be difficult to replicate. But deliberative scholars also give the example of the 'Stuttgart 21' project. There, sustained mass demonstrations forced German authorities to subject

\footnotetext{
${ }^{145}$ See C. Chwalisz, 'The Cry of Populism Signals a Wider Frustration with "Politics as Usual" and Greater Use of Deliberation Could Be the Answer', Democratic Audit, 24 August 2015.

${ }^{146}$ Chambers supra n. 117 at p. 371.

147 J.S. Dryzek et al., 'The Crisis of Democracy and the Science of Deliberation: Citizens Can Avoid Polarization and Make Sound Decisions', Science, 15 March 2019 at p. 1145.

148 To read more about the Brexit citizen assembly, see The Constitution Unit, Citizens' Assembly on Brexit, <https://www.ucl.ac.uk/constitution-unit/research/europe/citizens-assembly-on-brexit> accessed 20 August 2019.

${ }^{149}$ Dryzek et al. supra n. 147 at p. 1146.
} 
a controversial railway project to public dialogue and resulted in official State guidelines requiring citizen deliberation in the context of large infrastructural projects. ${ }^{150}$

Thus, political buy-in may be forced under conditions of public pressure or may occur on its own (perhaps once the levers of power change hands). What this article has sought to provide has been a normative case for where to turn once this happens, especially so as to try to prevent populist relapse. Deliberative democracy will likely itself need to adapt if it is to rise to the challenge of populism. ${ }^{151} \mathrm{~A}$ full discussion of what those adjustments may need to be goes beyond the scope of this article. Nevertheless, it is worth noting that deliberative democrats have for some time entertained how to make deliberation viable in the messy real world, so they are not entirely ill-equipped to address the populists' challenge. ${ }^{152}$

\section{Conclusion}

The aim of this article has been two-fold. First, it has challenged easy assumptions about the rise of populism in Central and Eastern Europe. To the extent that recent developments in countries such as Hungary, Poland or Romania continue to be attributed solely to distinctive pathologies of the region - marred as it is by weak institutions, corruption and underdeveloped civil society - they miss an important aspect. The appeal of populism cannot be divorced, I have argued, from the resonance of many of their claims with long-standing discontent with liberal democracy. This is not the same as arguing for populists as undercover democrats, but it does require a serious engagement with the popular disillusionment with democracy they have exploited.

Second, this article has posited that solutions proposed hitherto to the problem of populism in Central and Eastern Europe -notably the strengthening of counter-majoritarian institutions and the adoption of substantive notions of constitutionalism, plus a more forceful role for the EU - are premised on a 'more of the same' logic. They push for more liberal democracy despite its severe contestation, both before and during the current populist rise. Instead, I have called for a broader reorientation of democratic commitments, away from institutions and practices based on distrust of citizens and elite control and closer to those placing the citizen centre-stage as an empowered actor.

The article has explored the potential of deliberative democracy to provide the answers. Looking at its underpinning principles and practical instantiations, as well as its prospects in Central and Eastern Europe, I have argued that there is fertile ground for looking to deliberative democracy for a way out of the current state of affairs. Whether it be by the creation of deliberative institutions or else rendering existing representative institutions more deliberative, there is reason to believe that such measures would help alleviate the sense of alienation from politics widespread in the societies currently under populism's spell. Providing the spaces for addressing legitimate popular grievances should accompany calls for stronger rule of law protections in Central and Eastern Europe. These spaces must be participatory and deliberative if they are to be effective.

\footnotetext{
150 Ibid.

151 N. Curato and L.J. Parry, 'Deliberative Democracy Must Rise to the Threat of Populist Rhetoric', The Conversation, 7 June 2017.

152 See A. Fung, 'Deliberation before the Revolution: Toward an Ethics of Deliberative Democracy in an Unjust World', Political Theory (2005) p. 397, as well as Dryzek supra n. 110.
} 